\title{
Improving the Relationship between Higher Education Institutions and Business Environment in South-Eastern Europe: A Case Study
}

\author{
I. Tache ${ }^{1}$, G. Bratucu ${ }^{2}$, I. B. Chitu ${ }^{3}$, L. Dovleac ${ }^{4}$
}

\begin{abstract}
:
In the context of aligning South Eastern European countries to the EU requirements, the aim of this paper is to provide solutions for improving the relationship between the market of higher education services and labour market in Romania.

For achieving this aim, a quantitative marketing research was developed regarding the economist students' opinions on the training level provided by higher education institutions for labour market integration. The research sample includes 1683 students from 9 representative Romanian universities.

Research objectives were to quantify the economist students' interest in being employed during the study period, the type of knowledge provided by higher education institutions, the essential skills and competences to be acquired during college study.
\end{abstract}

Keywords: Higher education institutions, business environment, competitiveness, Romania.

${ }^{1}$ Corresponding author Ileana Tache - e-mail: ileana.tache@unitbv.ro Department of Marketing, Tourism-Services and Business Administration, Faculty of Economic Sciences and Business Administration, Transilvania University of Brasov.

${ }^{2}$ Gabriel Bratucu - e-mail: gabriel.bratucu@unitbv.ro Department of Marketing, TourismServices and Business Administration, Faculty of Economic Sciences and Business Administration, Transilvania University of Brasov.

${ }^{3}$ Ioana Bianca Chitu - e-mail: ioana.chitu@unitbv.ro Department of Marketing, TourismServices and Business Administration, Faculty of Economic Sciences and Business Administration, Transilvania University of Brasov.

${ }^{4}$ Lavinia Dovleac - e-mail: lavinia.dovleac@unitbv.ro Department of Marketing, TourismServices and Business Administration, Faculty of Economic Sciences and Business Administration, Transilvania University of Brasov. 


\section{Introduction}

In the last years, young people are struggling more and more with finding a job according to their education, this having a real long-term impact not only on their lives but also on the economy. According to Eurostat (2017), almost 20\% of the young people in the European Union (EU) is unemployed. According to Eurostat, as compared to December 2016, in December 2017 youth unemployment decreased by 411000 persons in the EU-28. The lowest rates were in the Czech Republic (4.9\%), Germany (6.6\%) and Estonia (6.8\%), while the highest were recorded in Greece (40.8\% in October 2017), Spain (36.8\%) and Italy (32.2\%) (Eurostat, 2017).

Unemployment, poverty and job insecurity are the biggest concerns for youth across South Eastern Europe (SEE). Therefore, emigration intentions are high, which is the strongest threat to any potential youth contribution to a better future (Taleski and Hoppe, 2015; Sultanova and Chechina, 2016).

In South Eastern Europe, unemployment is more than twice as high for youth as for adults. This is the case of six countries of the Western Balkans: Albania, Bosnia and Herzegovina, Kosovo, FYR Macedonia, Montenegro, and Serbia (SEE6). In 2013, the average youth unemployment rate in the European Union was about $26.4 \%$, while in South Eastern Europe it was 48\% (Word Barnk Group, 2016).

Some important reasons for youth unemployment in the EU appear to be the lack of professional experience and a growing mismatch between the youth skills and the positions offered on the job market. Starting from these aspects, the authors considered important to conduct a research regarding the Romanian students' opinions on the difficulties of their integration into the labour market.

\section{South Eastern Europe in the EU context of university-business cooperation}

The countries of South Eastern Europe (Romania, Bulgaria and Western Balkans countries) are implementing the Bologna Process with an orientation towards the present EU policy, especially the Lisbon Strategy. They have started to align their policies towards the strategic EU goals (economic growth, creation of jobs, investment in higher education and research), which are pertinent goals for the region (EUA, p. 1). According to EUA 2007 (p. 9), the Bologna Process is perceived as providing a direction that is essential for social development. Romania and Bulgaria joined Bologna Process in 1999, Croatia in 2001, Albania, BosniaHerzegovina, Macedonia, Montenegro and Serbia in 2003, Moldova in 2005 and Kosovo has an observer status.

These countries follow very attentively the university-business cooperation promoted by the European Union, considering that closer links between business and 
academia that can encourage the transfer and sharing of knowledge, create long-term partnerships and drive innovation, entrepreneurship and creativity.

The key findings of "The State of University-Business Cooperation in Europe" study (European Commission, 2017) show that:

- $85 \%$ of European business cooperate with higher education institutions;

- $99 \%$ of businesses plan to maintain or increase the university-

Business cooperation;

- $98 \%$ of academics plan to maintain or increase the university-business

Cooperation;

- 50\% of European academic respondents cooperate with business in either research or cooperation.

In this context, the new EU members of South Eastern Europe and the Western Balkans states should be aware that universities of their countries are extremely important for business innovation, education and recruitment. At the same time, they could extract significant initiative models from the recommendations for successful university-business cooperation (European Commission, 2017). Here are the most important ones:

- allow flexibility for institutions to achieve the targets of university business cooperation;

- support small scale bottom up initiatives rather than top down initiatives; focus on enablers and help them to scale-up their activities;

- promote entrepreneurship and student work place engagement at an early stage in education;

- enable students, and not just staff, to form links between companies and universities;

- consider how the Erasmus for Young Entrepreneurs programme can contribute to involving more students in entrepreneurship.

\section{Theoretical background}

O'Reilly et al. (2015) arrived at the conclusion that five factors characterize the youth unemployment in Europe: flexibility, education, migration, family legacies an EU Policy. So, the level of youth unemployment must be interpreted "in the context of increased labor market flexibility, an expansion of higher education, youth migration, and family legacies of long-term unemployment".

At the same time, higher education "is becoming a global service delivered by quasicompanies in an ever-more complex and competitive knowledge marketplace" and needs to have appropriate strategies (Pucciarelli and Kaplan, 2016). 
A comparative analysis of higher education and labor market in four European countries reveals that even if there are differences between educational systems and labor market trends, the expectations of employers and students are similar, with few differences (Branine, 2015). Students and their family expect that a degree diploma will deliver an education and a good job (Beverley, 2015) and firms expect young people well educated and with necessary skills.

McMurray et al. (2016) indicate a series of factors that employers consider in recruiting process (personal attitude, employability skills, relevant work experience and degree result), showing also the importance for graduates to develop job skills and for universities to develop business courses.

The need for higher education to focus more on practice appears in many researches. The economic education has often been criticized because: it fails to give the necessary knowledge and skills, does not train the needed leaders and their graduates do not perform as expected (Bennis and O'Toole, 2005; Teece, 2011; Muff, 2012; Örtenblad et al., 2013; Vovchenko et al., 2017).

The literature indicates a need for students' entrepreneurial skills in higher education for better chances on labor market. Students with entrepreneurial skills are assumed to be more market aware and creative in their job search (Kucel et al., 2016; Tymon, 2013). Another study suggests the value of internship as a method to enhance student's employability and a method to serve the interns, the employers and the universities (Helyer, 2014; Chillas, 2015). In the same idea, Lange et al., (2014), after a research involving 29 European countries, arrived at the conclusion that young people can profit if the educational system is more vocational oriented. A study made on Norway master's degree students six months after graduation shows that $77 \%$ of the students interacting with firms during their studies have better labor market situation than their colleagues (Thune and Støren, 2015).

Another important issue of increasing the employability of future graduates is the university curriculum. In this respect, there are authors that propose a "conceptual idea of social partnership in the design of educational programs", a partnership between universities and specialists from regional entities of labour market (Cai et al., 2017). Universities must be capable to anticipate changes and to model the curricula in accordance to these changes in all sectors of society. The higher education must indeed develop competencies for young people to be able to perform in the global context and to adapt continuously through lifelong learning (Ilie and Bondrea, 2016). A study made in Portugal reveals the need for a closer cooperation between firms and universities for enhancing the employability of graduates. During the training period firms discover some problems in students' abilities like the properly managing of time, communications skills, work in a team, heaving an entrepreneurial view (Pujol-Jover et al., 2015). 
In this context, the main purpose of this paper is to provide solutions for improving the relationship between the market of higher education services and labor market in Romania by identifying the economist students' opinions on the competences developed by higher education institutions for labor market integration.

\section{Research methodology}

To achieve this objective, the authors have included in the researched population students from 9 university representative centres of Romania having faculties with socio-human profile. Before implementation, the questionnaire was pretested on a sample of 70 persons. The empirical research was developed in October-November 2016. The questionnaire was posted on the platform Google Docs (Form function). Finally, there were 1683 answers that were validated, obtained from the students enrolled in researched universities at two university programs: Bachelor and Master.

The sample structure on university centres and study programs consists of $57.9 \%$ bachelor students and $42.1 \%$ master students. Processing of collected data from respondents was made by using the software SPSS 19.0. For validating the respondents' answers, the statistical chi-square test was used in several situations. The sample structure on university centres and study programs is presented in the following table (Table 1).

Table 1. Sample structure on university centers and study levels

\begin{tabular}{|l|l|l|l|l|}
\hline Universities included in the sample & \multirow{2}{*}{$\begin{array}{l}\text { Institution } \\
\text { size }\end{array}$} & \multicolumn{2}{|l|}{ Study level } & Total \\
\cline { 4 - 5 } & & Bachelor & Master & \\
\hline $\begin{array}{l}\text { Academy of Economic Studies of } \\
\text { Bucharest }\end{array}$ & $\begin{array}{l}\text { Very } \\
\text { large }\end{array}$ & $9.7 \%$ & $37.8 \%$ & $21.9 \%$ \\
\hline Babes Bolyai University of Cluj Napoca & \multirow{4}{*}{ Large } & $22.9 \%$ & $8.5 \%$ & $16.6 \%$ \\
\hline West University Timișoara & & $4.2 \%$ & $18.6 \%$ & $10.5 \%$ \\
\hline Alexandru Ioan Cuza University of Iași & & $15.9 \%$ & $2.6 \%$ & $10.1 \%$ \\
\hline Transilvania University of Braşov & \multirow{4}{*}{ Medium } & $32.9 \%$ & $13.1 \%$ & $24.3 \%$ \\
\hline Lucian Blaga Universitatea of Sibiu & $4.7 \%$ & $7.1 \%$ & $5.8 \%$ \\
\hline University of Craiova & & $3.5 \%$ & $4 \%$ & $3.7 \%$ \\
\hline Dunărea de Jos University of Galați & \multirow{3}{*}{ Small } & $3.7 \%$ & $4.9 \%$ & $4.2 \%$ \\
\hline 1 Decembrie 1918 University of Alba Iulia & & $2.4 \%$ & $3.5 \%$ & $2.9 \%$ \\
\hline Total & & $100 \%$ & $100 \%$ & $100 \%$ \\
\hline
\end{tabular}

Source: Data processed by authors.

Half of the universities centres selected are considered large and very large and that is the reason for the high percentages of respondents compared to the rest. The large share of respondents from Transilvania University of Brasov (23.1\%) as compared to the other universities could be considered a research limitation. This proportion of respondents was achieved due to the direct involvement of the authors in encouraging the students to fill in the questionnaires. In the other universities they didn't have the same opportunity. 


\section{Results and discussions}

The research results indicate that one out of eight students applied for a job during academic studies. From them, 97.6\% were looking for jobs inside the country. The main channels for applying for a job were online recruitment platforms (55\%) and attending the career fairs $(25 \%)$, where the students have the possibility of interacting directly with the recruiters. The online recruiting platform is a channel more and more used by young people in searching of jobs. This application allows the companies to post vacant job positions and the students have the chance to apply. Also, social media is another communication channel between job seekers and the employers.

The research results indicate that from those students who were seeking for a job, $62.7 \%$ are Master students and $37.3 \%$ are Bachelor students. To verify if the study level influences the decision of being employed during university studies, a chisquare test was used considering the following statistical hypothesis:

$\left(H_{0}\right)$ The study level has no influence on the student decision of being employed.

Table 2. Results of the chi-square test

\begin{tabular}{|c|c|c|c|c|c|}
\hline & Value & df & $\begin{array}{l}\text { Asymp. Sig. } \\
\text { (2-sided) }\end{array}$ & $\begin{array}{l}\text { Exact Sig. } \\
\text { (2-sided) }\end{array}$ & $\begin{array}{l}\text { Exact Sig. } \\
\text { (1-sided) }\end{array}$ \\
\hline Pearson Chi-Square & $64.313^{\mathrm{a}}$ & 1 & $.000 *$ & & \\
\hline Continuity Correction ${ }^{\mathrm{b}}$ & 63.323 & 1 & .000 & & \\
\hline Likelihood Ratio & 63.658 & 1 & .000 & & \\
\hline Fisher's Exact Test & & & & .000 & .000 \\
\hline Linear-by-Linear Association & 64.275 & 1 & .000 & & \\
\hline $\mathrm{N}$ of Valid Cases & 1683 & & & & \\
\hline \multicolumn{6}{|c|}{ a. 0 cells $(, 0 \%)$ have expected count less than 5 . The minimum expected count is 140.28 . } \\
\hline \multicolumn{6}{|l|}{$\begin{array}{l}\text { b. Computed only for a } 2 \times 2 \text { table } \\
* p<0.05\end{array}$} \\
\hline
\end{tabular}

Source: Data processed by authors.

According to the data of Table 2, the significance level $\mathrm{p}<0.05$ leads to the conclusion that the study level influences the students' decision of being employed. This is a natural behaviour because after the first study level completed (the bachelor), the students feel empowered to have a job.

From all the interviewed students who applied for a job, only a percentage of $10.1 \%$ say that they didn't face any barriers on the process. For the others, the main barriers mentioned were: faculty profile $(31.04 \%)$ and the lack of experience $(38.66 \%)$, according to the data presented in the following table. 
Table 3. Employment barriers by study level

\begin{tabular}{|l|l|l|l|}
\hline \multirow{2}{*}{ Barriers in getting a job } & \multicolumn{2}{|c|}{ Study level } & \multirow{2}{*}{ Total } \\
\cline { 2 - 4 } & Bachelor & Master & $31.04 \%$ \\
\hline Faculty profile & $28.22 \%$ & $39.27 \%$ & $38.66 \%$ \\
\hline Lack of experience & $27.75 \%$ & $53.78 \%$ & $30.3 \%$ \\
\hline Other barriers & $44.03 \%$ & $6.95 \%$ & $100 \%$ \\
\hline Total & $100 \%$ & $100 \%$ & \\
\hline
\end{tabular}

Source: Data processed by authors.

Looking from the study level perspective (Table 4), it can be noticed that more than half of the Master students $(53.78 \%)$ consider as a main hiring barrier the lack of experience in the field, as compared to $27.75 \%$ of the Bachelor students. This big difference between them is explained by the fact that employers ask more from the Master students in terms of experience than from Bachelor students. Inside the category "other barriers", the respondents mentioned the lack of knowledge of foreign languages, the mandatory attendance of academic courses or gender discrimination.

Regarding the importance of knowing foreign languages (mentioned as an employment barrier) more than one third $(32.7 \%)$ of the interviewed young people consider that they represent the main knowledge necessary for the integration into the labour market (Table 4). The higher interest expressed by students was for studying German, French and Spanish but also there were requests for Chinese or Russian. An important percentage of young people (20.1\%) consider being necessary to acquire practical skills. One out of the 10 respondents consider that for the integration into the international labour market it is necessary a cumulus of knowledge linked to foreign languages, practical skills and IT but also a theoretical specialization in the field and last, but not least, the capacity to work inside a team.

Table 4. The requests for the integration on the labour market by respondents' study level

\begin{tabular}{|l|l|l|l|}
\hline The requests for the integration on the & \multirow{2}{*}{$\begin{array}{l}\text { Total } \\
\text { labour market }\end{array}$} & Bachelor & Master \\
\hline Foreign languages & $32.7 \%$ & $42.7 \%$ & $25.4 \%$ \\
\hline Practical skills & $20.1 \%$ & $18.1 \%$ & $21.5 \%$ \\
\hline IT skills & $14.9 \%$ & $14.4 \%$ & $15,3 \%$ \\
\hline Theoretical knowledge & $11.5 \%$ & $8.7 \%$ & $13,6 \%$ \\
\hline Collaboration skills & $11 \%$ & $9 \%$ & $12.4 \%$ \\
\hline All mentioned above & $9.8 \%$ & $7.1 \%$ & $11.8 \%$ \\
\hline Total & $100 \%$ & $100 \%$ & $100 \%$ \\
\hline
\end{tabular}

Source: Data Processed by authors.

These results prove that the Master students consider that a professional must master the practical abilities to carry out their tasks of the job. On the other hand, those 
from the Bachelor level consider communication as being essential for a better integration at the job, relying more on interrelation than on individual knowledge.

Regarding the curriculum, the students consider that it should be oriented more towards social sciences and they gave some examples of disciplines that should be considered. The results are structured in Table 5 by respondents' study level.

Table 5. Preferred disciplines by study level

\begin{tabular}{|l|l|l|l|}
\hline \multirow{2}{*}{ Preferred disciplines } & \multirow{2}{*}{ Total } & \multicolumn{2}{|c|}{ Study level } \\
\cline { 3 - 4 } & $73.3 \%$ & $71.8 \%$ & $74.8 \%$ \\
\hline International cultural studies & $65.4 \%$ & $56.7 \%$ & $73.7 \%$ \\
\hline Social psychology & $38.9 \%$ & $32.3 \%$ & $45 \%$ \\
\hline Sociology & $20.3 \%$ & $19.4 \%$ & $21.1 \%$ \\
\hline Ecology & $5.9 \%$ & $5.9 \%$ & $5.8 \%$ \\
\hline Anthropology & \multicolumn{2}{|}{} \\
\hline
\end{tabular}

Source: Data processed by authors.

The distribution on study levels shows the fact that a higher percentage of Master students wish to study the social sciences disciplines than the Bachelor students. The result confirms the specialists' statements, who consider that the competences of a valuable professional in the economic field is based on knowledge from different fields, as international cultural studies (Pfeffermann, 2016), psychology, sociology (McManus, 2014) and anthropology (Maerki, 2008).

The same need for changing the curriculum structure arise from the higher percentages of students who want to attend an additional training course (from outside the university) to complete their competences and skills in the field. So, a percentage of $36.2 \%$ of Bachelor students and $63.8 \%$ of Master students expressed their need and possible the intention of completing their knowledge elsewhere.

The opinion of most of the students (68.9\% of cases) is that the Romanian education system develops just $a$ theoretical training. Developing skills is seen because of education only in $25.8 \%$ of cases (Table 6).

Table 6. The results of education by study levels

\begin{tabular}{|l|l|l|l|}
\hline \multirow{2}{*}{$\begin{array}{l}\text { The results of the Romanian economic } \\
\text { education }\end{array}$} & \multicolumn{2}{|c|}{ Study level } & \multirow{2}{*}{ Total } \\
\cline { 2 - 3 } & Bachelor & Master & $5.3 \%$ \\
\hline Talents & $4,3 \%$ & $5.8 \%$ & $25.8 \%$ \\
\hline Skills & $28.8 \%$ & $21.8 \%$ & $68.9 \%$ \\
\hline Theoretical training & $66.8 \%$ & $72.4 \%$ & $100 \%$ \\
\hline Total & \multicolumn{3}{|l}{} \\
\hline
\end{tabular}

Source: Data Processed by authors.

The above results show that the opinion of students of both study cycles confirm the idea mentioned by other specialists (Datar et al., 2011) regarding the fact that there is a 
"gap between theory and practice". The distribution on study level shows the fact that the percentage of Master students who consider that the main result of the Romanian education system is theoretical training $(72.4 \%)$ is higher than the percentage of Bachelor students (66.8\%). This is a worrying result, because in Romania, Master students are interested to be employed more than Bachelor students and the training of competitive economists on the labour market supposes the completion of the theoretical knowledge with the experimental training (Muff, 2012).

The same Table 6 shows as well that positive changes have appeared in approaching the process of transferring knowledge achieved by the education system. The Bachelor students consider that the academic education also creates skills in a higher percentage than Master students (28.8\% as compared to $21.8 \%)$. Both Bachelor and Master students came with some proposals for the higher education institutions for increasing the chances of creating employable students: more options for internships inside companies during college (31.8\% of respondents), guest speakers from business environments (58.7\% of respondents), more mobility options for studying abroad but coming back for finishing the studies (9.5\% of respondents).

The research results show that 4 out of 10 students don't find a job offer correlated to their educational training and this is a reason why 8 students out of 10 works in a different field from that they studied for. Due to this situation, a significant percentage of students (42.2\%) expressed their intention to leave the country. Only 18\% are sure that they don't want to look abroad for a job. A very interesting fact is that a third of the students (30.5\%) are willing to start a business inside the country rather than being employed. Considering this intention, universities can influence students' attitudes and intentions towards entrepreneurship, contributing to their initiation and development, and their active support in this action.

\section{Conclusions}

The aim of this paper was to provide solutions for improving the relationship between the market of higher education services and labour market in Romania in the context of aligning Southern Europe to the EU standards. Based on the research results, the main solution in this case could be strengthening the ability of students to adapt to and to respond to the demands of the labour market. The essential research findings indicate that most students are interested in accessing the labour market since college, reflecting their awareness and need to start setting connections to build a career. The students are those who highlight that there are noticeable imbalances between theory and practice in higher education institutions.

One of the main challenges for the higher institutions from Romania is the slow adaptation of the curricula to the transformations and innovations on the constantly changing and evolving labour market. The content of the curricula need to be the result of a continuous adaptation process to the requirements of employers and society and to the challenges of the globalization and internationalization process. A 
possible solution for this challenge would be adding to the curricula interdisciplinary studies which ensure the graduates the extended economic knowledge to understand and adapt to the social-economic dynamics. Another challenge is that higher education institutions provide rather a theoretical background than a practical one for labour market. The theoretical support need to be complemented by activities that allow students to acquire knowledge and practical skills. So, for raising the knowledge and strengthening the connection between the academic and business environment, the higher education institution could search more options for students' internships inside companies or invite guest speakers from business environments to present their perspective and interacting with students.

Another solution for solving the problems raised in this study is to follow the series of European Commission initiatives supporting the links between higher education and business. A closer cooperation with business could help universities develop relevant curricula meeting the students' needs and giving them the right skills for the labour market. Some EU initiatives which higher academic institutions should be involved in are The University-Business Forum (held regularly in Brussels since 2008) and Knowledge Alliances (EU-funded partnerships between higher education institutions and companies).

\section{References:}

Bennis, W.G. and O'Toole, J. 2005. How business schools lost their way. Harvard Business Review, 83(5), 96-104.

Beverley, O. 2015. Redefining graduate employability and work-integrated learning: Proposals for effective higher education in disrupted economies. Journal of Teaching and Learning for Graduate Employability, 6(1), 56-65.

Branine, M. and Avramenko, A. 2015. A Comparative Analysis of Graduate Employment Prospects in European Labour Markets: A Study of Graduate Recruitment in Four Countries. Higher Education Quarterly, 69, 342-365.

Cai, J., Youngblood, V.T., Khodyreva, E.A., Khuziakhmetov, A.N. 2017. Higher Education Curricula Designing on the Basis of the Regional Labour Market Demands. EURASIA J. Math., Sci Tech.13(7), 2805-2819.

Chillas, S., Marks, A. and Galloway, L. 2015. Learning to labour: an evaluation of internships and employability in the ICT sector. New Technology, Work and Employment, 30, 1-15.

Datar, S.M., Garvin, D.A. and Garvin, G.P. 2011. Rethinking the MBA: Business education at a crossroads. Journal of Management Development, 30(5), 451-462.

EUA - European University Association 2006. Conclusions and recommendations for action adopted by participants in the meeting "Strengthening Higher Education and Research in South East Europe - Priorities for Regional and European Cooperation".

EUA 2007. Trends V: Universities Shaping the European Higher Education Area, by David Crosier, Lewis Purser and Hanne Smidt, Brussels University Association (EUA).

European Commission 2017. $7^{\text {th }}$ European University-Business Forum, "University-Business Cooperation - for Innovation and Modernisation", Forum Report 6-7 April 2017, The Square, Meeting Centre, Mont des Arts - Kunstberg, Brussels. 
Eurostat, 2017. Unemployment statistics. Available at: http://ec.europa.eu/eurostat/statisticsexplained/index.php/Unemployment_statistics.

Helyer, R. and Lee, D. 2014. The Role of Work Experience in the Future Employability of Higher Education Graduates. Higher Education Quarterly, 68, 348-372.

Ilie, L. and Bondrea, I. 2016. Developing Students' Competences For The Future - Key Priority In The Economics Of Universities. International Conference KNOWLEDGEBASED ORGANIZATION Vol. XXII No 12016.

Kucel, A., Róbert, P., Buil, M. and Masferrer, N. 2016. Entrepreneurial Skills and EducationJob Matching of Higher Education Graduates. European Journal of Education, 51, 7389.

Maerki, H.U. 2008. Are business schools studying and teaching the right things? Journal of Management Development, 27(4), 425-430.

McManus, T.E. 2014. Dreams, visions, and values in fundamental business education. Journal of Management Development, 33(1), 32-47.

McMurray, S., Dutton, M., McQuaid, R. and Richard, A. 2016. Employer demands from business graduates. Education and Training, 58(1), 112-132.

Muff, K. 2012. Are business schools doing their job? Journal of Management Development, 31(7), 648-662.

O' Reilly, D. 2015. Five Characteristics of Youth Unemployment in Europe Flexibility, Education, Migration, Family Legacies, and EU Policy. SAGE Open.

Örtenblad, A., Koris, R., Farquharson, M. and Bill Hsu, S. 2013. Business school output: A conceptualisation of business school graduates. The International Journal of Management Education, 11(2), 85-92.

Pfeffermann, G. 2016. GBSN's perspective on business education and globalization. Journal of Management Development, 35(7), 866-877.

Pucciarelli, F and Kaplan, F. 2016. Competition and strategy in higher education: Managing complexity and uncertainty. Business Horizons, 59(3), 311-320.

Pujol-Jover, M., Riera-Prunera, C. and Abio, G. 2015. Competences acquisition of university students: Do they match job market's needs? Intangible Capital IC, 11(4), 612-626.

Sultanova, V.A., Chechina, S.O. 2016. Human Capital as a Key Factor of Economic Growth in Crisis. European Research Studies Journal, 19(2), 72-79.

Taleski, D. andHoppe, B. 2015. Youth in South East Europe. Lost in Transition. Available at: http://library.fes.de/pdf-files/id-moe/11504.pdf.

Teece, D.J. 2011. Achieving integration of the business school curriculum using the dynamic capabilities framework. Journal of Management Development, 30(5), 499-518.

Thune, T. and Støren, A.L. 2015. Study and labour market effects of graduate students' interaction with work organisations during education: A cohort study. Education and Training, 57(7), 702-722, https://doi.org/10.1108/ET-10-2014-0126

Tymon, A. 2013. The student perspective on employability. Studies in Higher Education, 38(6), https://doi.org/10.1080/03075079.2011.604408.

Vovchenko, G.N., Albekov, U.A., Romanova, F.T., Epifanova, V.T. 2017. Study of Factor Which Facilitate Increase of Effectiveness of University Education. International Journal of Educational Management, 31(1), 12-20.

World Bank Group 2016. Youth Unemployment in South East Europe: 10 Key Messages. Available at: http://www.worldbank.org/en/region/eca/publication/youthunemployment-in-south-east-europe-10-key-messages. 